(RESEARCH ARTICLE)

\title{
Substitution of coconut milk and soybean tempeh flour to produce ice cream that qualified and healthy
}

\author{
Moh. Su'i *, Hendrawan Ardy Pradana, Suprihana and Frida Dwi Anggraeni \\ Faculty of Agriculture, Widyagama Malang University, Borobudur Street no. 35, Malang, 65128.
}

Publication history: Received on 26 October 2020; revised on 03 November 2020; accepted on 04 November 2020

Article DOI: https://doi.org/10.30574/wjarr.2020.8.2.0400

\begin{abstract}
Ice cream is generally processed from cow's milk which contains a lot of long-chain unsaturated fatty acids and animal protein so it is poorly for health. Some people also have lactose intolerance with cow's milk. Coconut milk contains medium-chain fatty acids which are very good for health. Tempeh is a vegetable protein that is easy to digest and very good for health. This study was aimed to know the best of coconut milk concentration and soybean tempeh flour proportion for ice cream from coconut milk. This study learned two factors that were arranged factorial. The first factor was soybean tempeh flour concentration that was consisted of 3 levels each of 5; 7.5; and 10\% (w / total weight). The second factor was coconut milk concentration that was consisted of 3 levels each of $12.5 ; 15 ; 17.5 \%$ (w / total weight). The experimental design used a Randomized Block Design (RCBD). The results of the study were coconut milk with a concentration $17.5 \%$ and soybean tempeh flour with a concentration 5\%, with a total solid of $28.60 \%$; protein of $6,33 \%$; fat of $6.33 \%$; ice cream dough viscosity of $3.17 \mathrm{dPa}$.s; overrun of $10.26 \%$; melting speed of $1.16 \%$ min- 1 . Taste score 5.30 (likes); color score 5.35 (likes); flavour score 5.10 (likes); and texture scores 5.35 (likes).
\end{abstract}

Keywords: Ice Cream; Coconut Milk; Soybean; Tempeh

\section{Introduction}

Ice cream is a dairy frozen food product that made from milk and milk products, sweetener, stabilizer, emulsifier, and flavor enhancer [1]. Ice cream is one of the most popular dessert in the world. Ice cream production in 2003 reached more than 1 billion liters [2]. Ice cream consumption in 2019 reached 0.8 liters per capita every year. One of ice cream producer in Indonesia, in 2019 could produce 100 billion liters every year [3].

The main raw material of ice cream is milk. This condition causes some people cannot consume ice cream because the reason such as allergy, lactose intolerance and adhering to a vegetarian diet [4]. Therefore, needs for develop ice cream products based on vegetable ingredients.

Vegetable material that is potential to substitute milk as a source of fat is coconut milk. Fat content of coconut milk per 100 grams of material is 21.33 grams [5].

Coconut milk has been developed into Coconut Drink Powder (CDP). CDP is made from young coconut flesh or old and then was added young coconut water or old and was added maltodextrin then homogenized. Furthermore, it was dried using a spray dryer, so that was obtained coconut drink powder. The results showed that CPD was potential for further developed were formulas that were processed from old coconut water with the addition of $20 \%$ young coconut flesh [6]

\footnotetext{
${ }^{*}$ Corresponding author: Moh. Su'i

Faculty of Agriculture, Widyagama Malang University, Borobudur Street no. 35, Malang, 65128

Copyright (C) 2020 Author(s) retain the copyright of this article. This article is published under the terms of the Creative Commons Attribution Liscense 4.0.
} 
Fractionated coconut milk produces a fraction that is rich in lauric acid. The amount of lauric acid reaches $50.45 \%$. Besides lauric acid, it also contains medium chain fatty acids such as caproic acid $0.11 \%$, caprylic acid $5.52 \%$, capric acid $6.46 \%$ and myristic acid $17.52 \%$ [7].

Lauric acid, capric acid and myristic acid were very useful as an anti-bacterial [8], it could inhibit the HIV viruses development [9].

Lauric acid from coconut milk can inhibit the growth of Salmonella sp., E. Coli and Staphylococcus aureus at a concentration of $3.13 \%$. Micrococcus was inhibited at a concentration of $10 \%$, Bacillus stearothermophillus $30 \%$ and Pseudomonas at a concentration of 50\%. Lauric acid can kill Salmonella at a concentration of 3.13\%, E. coli and Staphylococcus aureus 6.25\%. Micrococcus at a concentration of 30\%, Bacillus stearothermophillus $50 \%$ and Pseudomonas at a concentration of 70\% [10].

The addition of coconut milk in production of ice cream has been done by several previous researchers. The combination of $75 \mathrm{~g}$ coconut milk and $25 \mathrm{~g}$ of cassava flour produces the best melting time ice cream of 19.44 minutes and a fat content of $46.41 \%$ [11].

The addition of avocado as much as $20 \%$ and pandan aromas as much as $2 \%$ produces the best ice cream with a moisture content of $36.33 \%$, protein $1.61 \%$, fat $23.53 \%$, overrun $37.17 \%$, melting speed 62.62 minutes, flavor values 5.35 , colors 5.75 , aromas 5.65 and textures 5.65 [12].

Comparison of tempeh milk: purple sweet potato $=12.5 \%: 17.5 \%$ ) produces vegetable ice cream with a total solids of $44.81 \%$, crude fiber $7.32 \%$ (wb), and antioxidant activity $1.33 \%$ DPPH per mg , overrun $80.43 \%$, and resistance 44.28 minutes [13].

The addition of $25 \%$ coconut milk and 5\% purple sweet potato porridge is the best treatment with $10.57 \%$ fat content, $1.90 \%$ protein content, $36.78 \%$ total solids, $24.33 \%$ overrun, 13.72 minutes melting time , purple (2.97), sweet (3.47), not rancid (2.30) and soft (2.90), favored by panelists with a score (2.87) [14].

According to [15], one of the key from ice cream quality is the percentage of fat. Fat makes soft ice cream in the mouth. In addition, the use of coconut milk as an ingredient can give a distinctive taste and aroma in ice cream products.

Vegetable ice cream that use of coconut milk as raw material still has shortcomings that is low protein levels. Protein content in coconut milk just only 2.02\% [5]. Quality standard of ice cream based on the Indonesian National Standard (SNI) 01-0317-1995 is requires a minimum protein content of $2.70 \%$ (w / w). To increase protein content in ice cream which based on this coconut milk, it is necessary to add solid ingredients that contain high protein such as soybean tempeh flour. Soy tempeh flour that contain protein is $43.03 \%$ [16].

Tempeh has nutritional value that higher than soy. There were an increase in free amino acids during the fermentation process, which was between 7.3 to $30 \%$ [17]. The increase of amino acid will increase protein digestibility that reach $80-90 \%$. During fermentation will also occur lipase, protease, amylase, and phytase enzyme production that could increase fat, protein, and carbohydrate digestion [18].

The amino acid in tempeh are dominated by arginine 6,58\%. While lysine and methionine are very low respectively 0,95\% and 0,15\% [19]. Arginine tends can decrease cholesterol level, whereas methionine and lysine precisely can increase cholesterol [20]. Methionine and lysine are amino acid that widely contained in animal protein. While arginine is a lot in vegetable protein. Methionine is homosystein precursor that a risk factor for coronary heart disease [19]. So that, the addition of tempeh flour to the ice cream is very beneficial for healthy.

The addition too much of coconut milk concentration can create a soft ice cream texture but the melting rate becomes faster, and vice versa. In the addition too much of soy tempeh causes the ice cream texture becomes hard and difficult to melt, and vice versa.

Based on the description above, it is necessary to conduct research to determine the combination of coconut milk with soy tempeh flour as the main solid material for physical, chemical, and organoleptic characteristics of ice cream products. 


\section{Material and methods}

This study was conducted in the Chemistry laboratory of Widyagama University of Malang and PT. Idolakto, Pandaan, Pasuruan. The main ingredients were fresh soybean tempeh and coconut milk in packaging (Brand "KARA"), shortening, lecithin, sugar, boiled water, and Na-CMC had been obtained from minimarket in Malang. The tools that were used in the ice cream manufacturing process were ice cream maker with brand Gaggia Gelatiera, freezer and refrigerator, centrifuge, distillator, analytical scale, gas stove, sieves, thermometer, pan, knives, basins, plastic containers / jars, and stirrer.

The research was conducted with two factors, there were 1: Soybean Tempe Flour and 2: Coconut Milk Concentration. The first factor contain of three levels, namely 5\%, 7.5\% and 10\% (of ICM weight). The second factor contain of three levels: $12.5 \%$; $15 \%$ and $17.5 \%$ (by ICM weight). This study used a Randomized Block Design (RCBD).

\subsection{The Making of Soy Tempe Flour}

Fresh soybean as raw material was thinly sliced. Then, it was heated with blanching method at a $90^{\circ} \mathrm{C}$ for 15 minutes in order to eliminate the unpleasant taste and aftertaste from the flour / tempeh that had been produced. After that it was cooled to room temperature. Sliced tempeh was dried in a cabinet dryer at $60^{\circ} \mathrm{C}$ for 24 hours. Tempeh that has been dried was crushed with a blender to get tempeh flour. Then, tempeh flour was sieved to obtain uniform particle size (100 mesh).

\subsection{The Making of Coconut Milk Ice Cream}

The ingredients were weighed according to the amount needed, namely sugar, $15 \%$ (w / total ICM weight), white butter $0.25 \%$ (w / total ICM weight), Na-CMC, $0.35 \%$ (w / total weight ICM), and soy lecithin $0.35 \%$ (w / total ICM weight). While soybean tempeh flour was varied to be $5 \%, 7.5 \%$ and $10 \%$ (of ICM weight).

Coconut milk solution was made by dissolving a certain amount of coconut milk in packaging into boiled water according to the desired concentration. The concentration of coconut milk solution was varied to $12.5 \% ; 15 \%$; and $17.5 \%(\mathrm{w} / \mathrm{w})$ of total weight = ICM (1 liter).

All ingredients that have been weighed according to the amount needed were mixed, and then added coconut milk solution until the total weight of the mixture reached $100 \%(\mathrm{w} / \mathrm{w})$. The mixture of ingredients was heated (cooked) over a fire while stirring until all ingredients dissolved. The temperature was maintained at $40^{\circ} \mathrm{C}$ so that the coconut milk emulsion did not break. The mixture continued to be heated until reached a temperature of $50{ }^{\circ} \mathrm{C}$ and then pasteurized at $80^{\circ} \mathrm{C}$ for 25 seconds until the temperature reached $65^{\circ} \mathrm{C}$. After the pasteurization process was carried out, the heating process was stopped.

The process was continued by homogenizing the mixture using a mixer at I speed (110 rpm) for 10 minutes. The ice cream mixture (Ice Cream Mix / ICM) then was fleshed (stored) in a refrigerator at $4^{\circ} \mathrm{C}$ for 16 hours. Furthermore, the ice cream mixture (Ice Cream Mix / ICM) was foamed in Ice Cream Maker with a temperature of $-1^{\circ} \mathrm{C}$ for 15 minutes.

The foamed of ice cream dough was packaged in a closed container and frozed in a freezer at $-5^{\circ} \mathrm{C}$ for 3 hours. After the freezing process was complete, ice cream could be tested for fat content, protein content, total solids, melting speed, overrun, organoleptic, color, taste, aroma, texture.

Research data were analyzed using analysis of variance. If there were differences then continued the LSD test.

\section{Results and discussion}

\subsection{Characteristics of Raw Materials}

Raw materials analysis of coconut milk and soybean tempeh flour had been carried out to find out some chemical and physical characteristics of these materials. The average raw material analysis results were presented in Table 1. 
Table 1 Chemical and Physical Caracteristics Analysis of Tempe Flour and Coconut milk.

\begin{tabular}{|l|l|l|}
\hline Parameters & Tempe Flour Soybean & Coconut Milk \\
\hline Protein Level (\%) & 40.73 & 4.13 \\
\hline Fat level (\%) & 12.50 & 24.33 \\
\hline Water content (\%) & 3.67 & 70.92 \\
\hline Total Solids (\%) & 96.33 & 29.08 \\
\hline Viscosity (Pa.s) & & 2.08 \\
\hline
\end{tabular}

\subsection{Chemical Characteristics of Coconut Milk Ice Cream}

\subsubsection{Total Solid}

The total of coconut milk ice solids that was produced due to variations of coconut milk solution concentration and the proportion of soy tempeh flour were presented in Table 2

Table 2 Total of Coconut Milk Ice Cream Solids in Variation Concentration Of Coconut Milk And Soy Tempe Flour

\begin{tabular}{|l|l|l|}
\hline Coconut Milk Concentration (\%) & $\begin{array}{l}\text { Soy Tempeh Fluor } \\
\text { Concentration (\%) }\end{array}$ & Total Solid (\%) \\
\hline 12.5 & 5 & $27.10 \mathrm{a}$ \\
\hline 15.0 & 5 & $27.41 \mathrm{ab}$ \\
\hline 17.5 & 5 & $28.60 \mathrm{bc}$ \\
\hline 12.5 & 7 & $29.67 \mathrm{c}$ \\
\hline 15.0 & 7 & $31.42 \mathrm{~d}$ \\
\hline 17.5 & 7 & $33.12 \mathrm{e}$ \\
\hline 12.5 & 10 & $33.03 \mathrm{ef}$ \\
\hline 15.0 & 10 & $34.45 \mathrm{ef}$ \\
\hline 17.5 & 10 & $37.68 \mathrm{~g}$ \\
\hline
\end{tabular}

Table 1 showed that, in $5 \%$ of soybean tempeh flour, an increasing in the coconut milk solution concentration almost did not increased of total solids. But in $7.5 \%$ of soybean tempeh flour and $10 \%$, an increasing of coconut milk solution concentration had increased of total solids. It was because by increasing coconut milk solution concentration, so that the amount of protein, carbohydrates and fats would increasing the total solids in ice cream.

According to [21], the increased of total solids was the result of an increasing all dough components presentation. Total solids was solid components that made a material like fat, protein, carbohydrates, and ash. The increased in total solids was expected could produce an ice cream texture smoother because it would cause inhibition of the crystal growth mechanism [22].

\subsubsection{Protein levels}

The increasing of the coconut milk amount would increasing the protein level of coconut milk ice cream (Table 3 ). This coconut milk was contain protein so that it would increasing protein level in vegetable ice cream. Raw materials analysis result (table 1) stated that coconut milk that was used contains protein level of $4.13 \%$. 
Table 3 Protein Level of Coconut Milk Ice Cream in Variation Coconut Milk Concentration

\begin{tabular}{|l|l|}
\hline Coconut Milk Concentration (\%) & Protein Level (\%) \\
\hline 12,5 & $7.62 \mathrm{a}$ \\
\hline 15.0 & $7.72 \mathrm{ab}$ \\
\hline 17.5 & $7.92 \mathrm{~b}$ \\
\hline
\end{tabular}

The higher of soybean tempeh flour concentration, so that the protein levels of coconut milk ice cream would also increase (Table 4). The average of protein levels of coconut milk ice cream that was produced due to variation of soybean tempeh flour concentration were presented in Table 4.

Table 4 Average of Protein Level of Coconut Milk Cream in Variation of Soy Tempe Flour Concentrations

\begin{tabular}{|l|l|}
\hline Soy Tempeh Fluor Concentration (\%) & $\begin{array}{l}\text { Protein Level } \\
(\%)\end{array}$ \\
\hline 5.0 & $6.21 \mathrm{a}$ \\
\hline 7.5 & $7.79 \mathrm{~b}$ \\
\hline 10.0 & $9.22 \mathrm{c}$ \\
\hline
\end{tabular}

This was because soy tempeh flour had protein content. Based on the analysis result of raw materials (Table 1 ) soybean tempeh flour that was used contains $40.73 \%$ protein. As the main raw material, both of these ingredients would contribute to protein in vegetable ice cream.

In the process of making ice cream, the functions of protein was to stabilize the fat emulsion after homogenization, add flavor, help foaming, increase and stabilize the water binding ability which affects the thickness of the ice cream and produce a soft texture, and increase overrun without affecting the texture and softness of the ice cream [1]. Besides its function on the physical properties of ice cream, the protein content was also expected to increase the nutritional value of ice cream.

\subsubsection{Fat level}

Increasing the amount of coconut milk would be increasing the fat level of coconut milk ice cream while the increase of soy tempeh flour did not affect in the fat levels of vegetable ice cream. Average of the fat level in vegetable ice cream due to the variation of coconut milk solution concentration was presented in Table 5.

Table 5 Average The Fat Levels of Coconut Milk Ice Cream in Variations Coconut milk Concentration

\begin{tabular}{|l|l|}
\hline Coconut Milk Concentration (\%) & Fat Level (\%) \\
\hline 12.5 & $5.82 \mathrm{a}$ \\
\hline 15.0 & $6.28 \mathrm{ab}$ \\
\hline 17.5 & $6.45 \mathrm{~b}$ \\
\hline
\end{tabular}

The increased of fat levels in ice cream was occurred because of coconut milk contained fat. The results of raw materials analysis (Table 1) stated that coconut milk that was used contain $24.33 \%$ of fat, so that in the making of this coconut milk ice cream, coconut milk was the main source of fat. The use of coconut milk solution with a concentration of 12.5$17.5 \%$ as a raw material, certainly would contribute to fat in vegetable ice cream, so that the used of the amount of fat source as raw material was greater, the fat content in a product would increase.

According to [1], that fat had an important role in the ice cream quality, namely increasing of ice cream nutritional value, adding flavor, producing a soft texture, helping to given form and density, and providing a good melting properties.

\subsubsection{Overrun}

The higher of coconut milk solution concentration that was used would reduce the overrun of vegetable ice cream dough. The average overrun of coconut milk ice cream dough that was produced due to variations in coconut milk concentration was presented in table 6 . 
The decrease in overrun was caused by the increasing of fat levels in ice cream. The size, amount and physical condition of the fat globules in the ice cream dough determined the rate of foaming and the foam stability that was formed. A small amount of fat globules could increase the foaming of dough which did not contained of fat foamed quickly, but produced of foam that was easy to shrink after being frozen. However, the use of fat in more amount would reduce the ability of the dough to foam (whipping ability) [23].

Table 6 Average Overrun of coconut milk ice cream due to variations of Coconut milk Concentrations

\begin{tabular}{|l|l|}
\hline Coconut Milk Concentration (\%) & Overrun (\%) \\
\hline 12.5 & $14.45 \mathrm{a}$ \\
\hline 15.0 & $13.41 \mathrm{a}$ \\
\hline 17.5 & $10.48 \mathrm{~b}$ \\
\hline
\end{tabular}

The protein source in coconut milk ice cream came from soybean tempeh flour. During the fermentation process of soybeans into tempeh, proteins were decomposed into free amino acids by the proteolytic activity of the R. oligosporus [24]. Decomposition of protein into free amino acids caused soy protein to lose its functional properties in foaming form.

\subsubsection{Melting Rate}

The increasing of coconut milk concentration would reduce the speed of melting vegetable ice cream or ice cream melted faster. The average melting rate of coconut milk ice cream that were produced due to variations in coconut milk solution concentrations were presented in table 7.

Table 7 Average Melting Rate of Coconut Ice Cream in Variation of Coconut Milk Solution Concentration

\begin{tabular}{|l|l|}
\hline Coconut milk Concentration (\%) & $\begin{array}{l}\text { Melting Rate } \\
\text { (minutes) }\end{array}$ \\
\hline 12.5 & $1.34 \mathrm{a}$ \\
\hline 15.0 & $1.05 \mathrm{~b}$ \\
\hline 17.5 & $0.91 \mathrm{~b}$ \\
\hline
\end{tabular}

The decrease in melting rate was thought because an increase in fat levels along with increasing of coconut milk solution concentration. In this case, the sidelines of the air acted as an insulator and fat would stabilize the foam structure, so that the melting rate was faster. [1] stated that a good ice cream was resistant to melting when served at room temperature.

Increasing of soy tempeh flour also decreased of vegetable ice cream melting rate. The average of coconut milk ice cream melting rate due to variations soybean tempeh flour proportions were presented in Table 8.

Table 8 Average Melting Rate of Coconut Milk Ice Cream in Variation Concentration

\begin{tabular}{|l|l|}
\hline Soy Tempeh Fluor Concentration (\%) & $\begin{array}{l}\text { Melting Rate } \\
\text { (minute) }\end{array}$ \\
\hline 5.0 & $1.42 \mathrm{a}$ \\
\hline 7.5 & $1.10 \mathrm{~b}$ \\
\hline 10.0 & $0.77 \mathrm{c}$ \\
\hline
\end{tabular}

Table 8 showed ice cream was faster to melt with the increased of soybean tempeh flour that was used. This was caused the increasing of soy tempeh flour proportion that was used, the total ice cream solids would increase as well. In the increasing of this total solids caused the foam cavities in the ice cream were bigger so that the melting rate was faster. [25] stated that the speed of ice cream melting was greatly influenced by total solids. 


\subsection{Vegetable Ice Cream Characteristics}

\subsubsection{Taste Preference}

The average score of panelist preference for the coconut milk ice cream taste due to variations in coconut milk solution concentrations and soybean tempeh flour proportions was ranged between 3.95-5.30 (somewhat dislike to like).

The level of panelist preference for coconut milk ice cream taste increased with the increasing coconut milk solution concentration. and decreased with increasing soy tempeh flour proportion.

Panelist did not like tempeh taste in ice cream because it still felt unpleasant and bitter (rather bitter). Panelists prefer ice cream with a combination of using $17.5 \%$ coconut milk solution and $5.0 \%$ soy tempeh flour because of the high concentration of coconut milk solution so that it could disguise the undesirable taste of soy tempeh flour.

[26] stated that the components of coconut milk (especially fat and protein) were able to form a distinctive taste and aroma. This taste and aroma could not be replaced by other ingredients so that the consumption of coconut milk remained extensive until now.

\subsubsection{Aroma Preference}

The average score of panelist preference for coconut milk ice cream aroma due to variations in coconut milk solution concentration and soy tempeh flour proportion ranged from 4.55-5.10 (neutral-like).

The level of panelist preference towards coconut ice cream tends to increase with an increase in coconut milk solution concentration, but had a tendency to decrease due to an increase in soy tempeh flour proportion. Just like with the taste scoring, panelist prefer ice cream with a high concentration of coconut milk solution because it could disguise the unpleasant aroma of soy tempeh flour. [26] stated that components of coconut milk (especially fat and protein) were able to form distinctive flavors and aromas. This taste and aroma could not be replaced by other ingredients so that the consumption of coconut milk remained extensive until now.

\subsubsection{Texture Preference (Mouthfeel)}

The total mean of panelist preference for texture due to variations in coconut milk solution concentration and soybean tempeh flour proportion ranged from 4.80 to 5.70 (neutral-like).

The level of panelist preference on the texture of coconut milk ice cream that produced was more increase with an increase in coconut milk solution concentration and soy tempeh flour proportion. The more increase of coconut milk, panelist were more like, and the higher of soybean tempeh flour concentration, the more disliked by the panelist.

The increasing of coconut milk solution concentration and soy tempeh flour proportion that were used would result in an increase of fat content. An increase of fat content in ice cream would improve the texture of ice cream. According to [27], with a comparison of all factors, a high percentage of fat would give a soft texture where the fat was spread evenly with a homogeneous and small size. The increasing of the protein content in ice cream would increase the total solids so that it would improve the texture and melting rate on ice cream.

\section{Conclusion}

The coconut milk concentration gave a significant effect on the total solids, protein level, fat level, viscosity of the dough, overrun, and melting rate parameter. The soybean tempeh proportion had a significant effect on the total solids, protein level, viscosity of dough, and melting rate parameter. But it did not had a significant effect on the fat level parameter.

The best treatment in ice cream concentration of $17.5 \%$ coconut milk solution and 5.0\% soy tempeh flour. Physical and chemical characteristics of the ice cream was to contain a total solid of $28.60 \%$; $6.33 \%$ protein; $6.33 \%$ fat; viscosity of ice cream dough 3.17 dPa.s; overrun 10.26\%; melting rate 1.16 minutes. Flavor 5.30 (like), color 5.35 (like), aroma 5.10 (like) and texture 5.35 (like). 


\section{Compliance with ethical standards}

\section{Acknowledgments}

The authors gratefully thank to the PT Indolacto, Pandaan Indonesia for their support to this research.

Disclosure of conflict of interest

Authors declare that they have no conflict of interest.

\section{References}

[1] M. Padaga and M. E. Sawitri, Making Healthy Ice Cream, Trubus Agrisarana, 2005.

[2] M. Astawan, There is a Tamer Virus in Ice Cream. Retrieved on September 26, 2015 from http: //www.kompas.com-/k health/news/0507/2 sadc 8 / 112138.htm., 2008

[3] A. Hidayat and L. Febriani, The Indonesian Ice Cream Market is increasing, Kontan.co.id, Retrieved on August 29, 2019 from http://amp.kontan.co.id/news/pasar-es-krim-indonesia-semakin-bergairah, 2019.

[4] L. Soler, Development of Non-Dairy Frozen Dessert Containing Soy Protein and Coconut Milk. Thesis. Food Science Department of Louisiana State University, Louisiana, 2005.

[5] USDA, National Nutrient Database for Standard Reference of United States Department of Agriculture, 2014.

[6] B. Rindengan, S. Karouw, J. Towaha and R. Hutapea, The Effect of Comparison of Coconut Water and Addition of Young Coconut Meat and Storage Time on Coconut Drink Powder, Journal of Littri. 2007; 13 (2):73 - 80.

[7] M. Su'i, E. Sumaryati. and D.W. Sucahyono, Utilization of Lauric Acid-Rich Faction (Hydrolysis Results from Coconut Endosperm Using Endogeneus Lipase) as a Preservative of Soybean Milk Packaging, Agritech Journal of Agricultural Technology, University of Gajah Mada Yogyakarta. 2016; 36 (2):154-159.

[8] S. M. Vetter and Schlievert, Glycerol monolauric inhibits virulence factor production in Bacillus anthracis, Antimicrob Agent Chemother, 2005; 49 (4):1302-1305.

[9] S.D. Conrado, Coconut Oil in Health and Disease: Its and Monolaurin's Potential as Cure for HIV / Aids, Cocotech Meeting XXXVIIth, Chennai, India, 2002 July 25.

[10] Su'i, M., E. Sumaryati, R. Prasetyo and DP Eric, Anti-Bacteria Activities of Lauric Acid from Coconut Endosperm (Hydrolyzed using Endogenous lipase), Advances in Environmental Biology. 2015; 9 (23):45-49.

[11] A.M. Koyo, A. Rokhayati and A.B. Rachman, Level of Use of Coconut Milk and Forest Sweet Potato Flour (Dioscorea Hispida Dennts) in Ice Cream Making, Agrosains. 2016; 2(1) : 16-24.

[12] S. Wijana, U. Effendi and E. Setiati, Optimization of avocado fruit added on the ice cream product of coconut milk, Journal of Agricultural Technology, 2001; 2(1):87-91.

[13] I. Filiyanti, D.R. Affandi and B.S. Amanto, A Study on the Use of Tempe Milk and Purple Sweet Potato as the Substitute of Skim Milk in Producing the Coconut Milk-Based Ice Cream Plant, Journal of Food Engineering Science. 2013; 2 (2):57-65.

[14] Jumiati, V.S. Johan and Yusmarini, The Study of Ice Cream Production From Coconut Milk and Purple Sweet Potato Puree, JOM Faperta. 2015; 2 (2):1-12.

[15] P.G. Strange, Antipsychotic drugs: the importance of dopamine receptors for mechanisms of therapeutic actions and side effects. Pharmacological Reviews. 2001; 53:119 -133.

[16] M. Rachmawati and F. Sumiyati, Tempeh Flour Business Guide Series. LIPI Scientific Documentation and Information Center. Jakarta, 2000.

[17] J.L. Kiers, Effects of Fermented Soya bean on Digestion, absorption and diarrhea (Disertation), Wageningen University, 2001.

[18] Hermana, M. Mahmud and D. Karyadi, Composition and Nutritional value of tempeh; its role in the improvement of the nutritional value of food, dalam "The complete hand book of tempeh", The American Soybean Association, 1999. 
[19] D.M. Utari, Rimbawan, H. Riyadi, Muhilal and Purwantyastuti, Potency of Amino Acid in Tempeh for Improving Lipid Profile and Diabetes Mellitus, Jurnal Kesehatan Masyarakat Nasional, 2011; 5 (4):166-170.

[20] J.J. Erdman, T. Badger, J. Lampe, K.K. Setchell, M. Messine, Not Soy Product are Created Equal: caution needed in interpretation of research result, The Journal of Nutrition, 2004; 134:S1229-1233.

[21] C. Kunchenbuch, Ice Cream, Retrieved on September 23, 2007 from: http: //www.wsu.edu/gmhyde/43 3_web_pages / 433 webpages 2001 / ice\% 20cream 2.html, 2000.

[22] W.S. Arbuckleand R. T. Marshall, Ice Cream 5th Edition. Cahmpman \& Hall. New York, 1997.

[23] R.T. Marshall, H. D. Goff, and R. W. Hartel, Ice Cream Sixth Edition. Kluwer Academic / Plenum Publisher. New York, 2003.

[24] M. Astuti, A. Meliala, F. S. Dalais and M. L. Wahlqvist, Tempeh, A Nutritious and Healthy Food from Indonesia. Asia Pacific Journal of Clinical Nutrition, 2000; 9(4): 322-325.

[25] E. Zubaidah, The Effect of Addition of Sorbitol and Covenant After Process to Product Storage (Typical Food of East Java). National Seminar. PATPI, 2002.

[26] R. Palungkuh, Various processed coconut products. Self-help Spreaders. Jakarta, 1993.

[27] L.E. Jeremiah, Freezing Effect on Food Quality. Marcell Dekker, Inc. New York, 1996. 